\title{
MINAT BACA MASYARAKAT PENGUNJUNG PERPUSTAKAAN DAERAH PROPINSI SUMATERA BARAT
}

\author{
Oleh : Firman
}

Fakultas Ilmu Pendidikan Universitas Negeri Padang

Email : firman@konselor.org

\begin{abstract}
This study aimed to show that : (1) reading interested of the library's visitors, (2) utilizing the library by people who visits it, and (3) to attain the improvement of reading interested in the school and public. This studied is descriptive study and the population is the society that using "Layanan Perpustakaan Daerah Propinsi Sumaera Barat" The sampling using "Two Stage Cluster Random Sampling Technique". The collecting data using questionnaire. The data is analyzed descriptively by using percentage. Based on this study it showed that: (1) the people who visits that library have not yet reading interested optimally toward the collection in the library, and (2) Most of people who visits that library only one day a week.The collection have not utilized yet by people who visits the library.
\end{abstract}

Kata Kunci : Perpustakaan, minat baca

\section{Pendahuluan}

Di era globalisasi kegiatan membaca menjadi kebutuhan utama dalam pengembangan Sumber Daya Manusia (SDM) menghadapi persaingan dengan bangsa-bangsa lain di dunia. Pemenuhan kebutuhan pembangunan SDM, pemerintah serta organisasi lainnya telah mendirikan berbagai perpustakaan untuk penyediaan informasi yang dibutuhkan masyarakat. Awal pendirian satu perpustakaan dengan perpustakaan lain berbeda, baik dari segi tujuan, anggota, organisasi dan kegiatan yang dilakukannya. Perbedaan kebutuhan pendirian perpustakaan tersebut, mendorong berdirinya berbagai jenis perpustakaan, diantaranya: (1) perpustakaan internasional, (2) perpustakaan nasional, (3) perpustakaan umum termasuk keliling, (4) perpustakaan sekolah , (5) perpustakaan khusus, (6) perpustakaan perguruan tinggi dan sebagainya.

Perpustakaan umum merupakan salah satu perpustakaan yang melayani masyarakat dari berbagai lapisan. Wahyu Edie Purnomo (Basuki,1994 : 10) menjelaskan perpustakaan umum adalah perpustakaan yang dibiayai dari dana umum, baik sebagian maupun seluruhnya. Selanjutnya perpustakaan tersebut terbuka untuk masyarakat umum tanpa membeda-bedakan usia, jenis kelamin, kepercayaan, agama, ras, pekerjaan, keturunan, serta memberikan layanan cuma-cuma untuk umum.

Keberadaan perpustakaan umum amat penting bagi kehidupan kultural dan kecerdasan masyarakat dan bangsa, karena perpustakaan umum merupakan satu-satunya pranata yang dapat diraih umum. UNESCO (Basuki, 1994 : 13) menjelaskan tujuan utama perpustakaan, adalah: (1) memberikan kesempatan bagi umum membaca bahan pustaka yang dapat membantu meningkatkan taraf hidup ke arah yang lebih baik, (2) menyediakan sumber informasi yang cepat, tepat, dan murah bagi masyarakat, terutama informasi mengenai topik yang berguna dan hangat dalam masyarakat, (3) membantu warga 
mengembangkan kemampuan yang dimilikinya sehingga yang bersangkutan akan bermanfaat bagi masyarakat sekitarnya, dan (4) bertindak selaku agen kultural, artinya perpustakaan umum merupakan pusat utama kehidupan budaya bagi masyarakat sekitarnya. Perpustakaan umum bertugas menumbuhkan apresiasi budaya masyarakat sekitarnya dengan cara menyelenggarakan pameran budaya, ceramah, pemutaran film dan penyediaan informasi yang dapat meningkatkan keikutsertaan, kegemaran dan apresiasi masyarakat terhadap segala bentuk seni budaya.

Kondisi perpustakaan di Indonesia sekarang secara umum masih lemah. Daud (Adiningsih, 2002) menjelaskan banyak ulasan tentang begitu menyedihkannya kondisi perpustakaan di Indonesia. Misalnya Perpustakaan Yayasan Hatta di Yogyakarta sudah kehilangan daya tarik sebagai sumber ilmu pengetahuan. Koleksi buku yang berjumlah 41.0147 eksemplar kian menyusut karena ada $40 \%$ buku tidak kembali, serta kegiatan ilmiah terhenti. Tahun 1986 di Indonesia terdapat 295 buah perpustakaan khusus, 252 perpustakaan universitas (negeri dan swasta), 111 perpustakaan keliling, 1.139 perpustakaan sekolah, 524 perpustakaan desa, 300 perpustakaan daerah (Provinsi/Kabupaten/Kota).

Berdasarkan penelitian Deputi Pengembangan Perpustakaan Nasional RI (Adiningsih, 2002) menunjukkan, baru 5\% dari sekitar 300.000 sekolah SD hingga SMU/SMK di Indonesia serta baru 20\% dari $66.000 \mathrm{desa/kelurahan}$ yang memiliki perpustakaan memadai. Buku sumbangan sangat sedikit yang dibaca pengunjung. Sejak Perpustakaan Nasional menerima publikasi penerbitan dari PBB dan badan dunia lain (mulai 1948), kini ada 6.746 judul, sekitar 12.000 eksemplar buku/jurnal (belum termasuk terbitan UNESCO yang berisi kegiatan badan-badan dunia). Akan tetapi ternyata sangat sedikit masyarakat yang memanfaatkannya. Data dari Kepala Sub Bidang Kerja Sama Perpustakaan Nasional RI memperlihatkan, pada 1995-1999 buku sumbangan dari PBB dan Bank Dunia hanya dibaca oleh 536 orang di Perpustakaan Nasional. Dengan kecenderungan kian menurun, dari 161 pembaca pada tahun 1995, 134 pembaca tahun 1996, 76 pembaca tahun 1997, 84 pembaca tahun 1998, dan 81 pembaca tahun 1999.

Berkurangnya pemanfaatan perpustakaan umum bersumber dari pembaca dan manajemen perpustakaan itu sendiri. Kekalahan masyarakat Indonesia dalam bersaing, salah satu hal disebabkan oleh budaya membaca dan belajar yang kurang mendukung, sehingga mengalami kesulitan memahami, menguasai, mentransfer dan menggunakan Ilmu Pengetahuan dan Teknologi (IPTEK) untuk produksi barang dan jasa bermutu.

Sejak Tahun 1989 Pemerintah Republik Indonesia telah mencanangkan wajib belajar enam tahun, kemudian pada 1994 dilanjutkan wajib belajar sembilan tahun (SD dan SLTP) sehingga bantuan buku bacaan dan pelajaran bertambah dari tahun ke tahun, namun demikian ternyata sebagian besar SD belum memiliki perpustakaan. Begitu juga bantuan berbagai buku untuk mengatasi jutaan penduduk usia produktif (15-44 tahun) kini juga belum dapat dimanfaatkan secara optimal karena sebagian desa belum memiliki perpustakaan. Di samping itu, upaya peningkatan kualitas pustakawan dalam pengelolaan perpustakaan telah diberlakukan oleh pemerintah melalui tenaga fungsional.

Berdasarkan studi pendahuluan pada bulan Juli sampai dengan Agustus 1993, ditemukan Perpustakaan Daerah Sumatera Barat melayani pengunjung di Perpustakaan Daerah, Perpustakaan 
Keliling yang beroperasi di Kota/Kabupaten dan Layanan Terpadu dengan empat belas Perpustakaan Sekolah di Sumatera Barat. Koleksi buku di Perpustakaan Daerah Sumatera Barat Tahun 2002, dimanfaatkan oleh pengujung sebanyak 98.406 orang, dengan rincian : 31.936 pelajar, 58.588 mahasiswa, 2.552 pegawai, 4.470 ABRI dan 3.560 orang dari masyarakat umum. Sedangkan jumlah buku yang disediakan untuk Perpustakaan Keliling sebanyak 34.258 judul dan 43.437 eksemplar, jumlah anggota 8.949 orang dan peminjam sebanyak 30.016 orang. Sedangkan buku yang disediakan untuk Layanan Terpadu Perpustakaan Sekolah sebanyak 12.885 judul dengan 15.415 eksemplar, jumlah anggota 1032 orang dan peminjam 1824 orang .

Bertitik tolak dari keterangan tersebut di atas, diasumsikan fasilitas yang disediakan Perpustakaan Daerah Sumatera Barat kurang dimanfaatkan masyarakat secara optimal. Pemanfaat perpustakaan hanya dilakukan oleh sebagian mahasiswa dan pelajar sehubungan dengan penyelesaian pendidikan. Pemanfaatan perpustakaan oleh pegawai dan masyarakat umum dalam pemenuhan kebutuhan ilmiah dan praktis sangat terbatas sekali.

Berbagai usaha sudah dilakukan Perpustakaan Daerah dalam meningkatkan minat baca masyarakat, diantaranya penambahan koleksi yang diminati peminjam/pemakai , di antaranya koleksi kelas 000 (karya-karya umum, ilmiah popular). Sistem pelayanan juga telah dimulai dengan komputerisasi program NCI Bookman v2.30, yang sampai dengan saat ini masih dalam tahap pemasukan data buku (judul, pengarang, subyek, abstrak, tampilan cover, dan data fisik buku lainnya). Namun demikian untuk penelusuran informasi keberadaan buku atau OPAC (Online Public Acces Catalog) telah dapat diakses melalaui "Network Neighborhood". Selain itu Perpustakaan juga tidak henti-hentinya menyebarkan "iklan layanan membaca" melalui selebaran atau leaflet yang berisi tentang manfaat membaca untuk memambah pengetahuan. Di samping itu, Perpustakaan Daerah Sumatera Barat telah melaksanakan Layanan Terpadu dengan Perpustakaan Sekolah. Namun demikian jumlah pengunjung dan buku yang dipinjam tidak mengalami peningkatan yang berati dari tahun ke tahun.

Bertitik tolak dari fenomena tersebut menarik ditelusuri lebih lanjut melalui penelitian ini minat baca masyarakat pengunjung Perpustakaan Daerah Propinsi Sumatera Barat sebagai sumber belajar. Pengungkapan minat baca masyarakat pengunjung Perpustakaan Darah Sumatera Barat bermanfaat dalam merumuskan kebijakan peningkatan pelayanan perpustakaan guna meningkatkan kualitas Sumber Daya Manusia.

\section{Metode Penelitian}

Penelitian ini merupakan penelitian deskriptif yakni menggambarkan fakta dan data sebagaimana adanya. Populasi penelitian ini adalah masyarakat pengunjung perpustakaan, terdiri dari siswa, pegawai dan masyarakat umum yang memanfaatkan Layanan Perpustakaan Daerah Propinsi Sumatera Barat. Menghindari kesulitan dalam menyusun sampling frame secara individu serta menjaring Pos Perpustakaan di Kabupaten/Kota, pengambilan sampel menggunakan teknik Two Stage Cluster Random Sampling. Pengunjung Perpustakaan Daerah diklasifikasi ke dalam dua starata, stratum pengunjung Perpustakaan 
Daerah dan Perpustakaan Keliling. Unit Sampling Primer (USP) adalah pengunjung perpustakaan dan Unit Sampling Sekunder (USS) juga menjadi unit observasi adalah pengunjung Perpustakaan Daerah teridiri dari siswa/mahasiswa, Pegawai/ABRI dan masyarakat umum. Pemilihan tahap pertama secara acak dipilih pengunjung perpustakaan dari masing-masing stratum. Pos terpilih yaitu Kota Padang, Kota Solok, Kabupaten Tanah Datar dan Pesisir Selatan. Pilihan tingkat kedua, dipilih pengunjung di Lokasi Pelayanan Kota Padang untuk Perpustakaan Daerah, sedangkan perpustakaan keliling yaitu pengunjung dari Kota Solok, Kabupaten Tanah Datar dan Pesisir Selatan. Jumlah pengunjung yang terjaring untuk sampel penelitian berjumlah 350 orang. Penelitian dilaksanakan pada bulan Juni sampai dengan November 2004 . Data yang diperlukan dalam penelitian ini dikumpulkan dengan kuesioner. Selanjutnya data dianalisis secara deskriptif dengan menggunakan persentase.

\section{Hasil Penelitian}

\section{a. Minat Baca Masyarakat Pengunjung Perpustakaan Daerah Propinsi Sumatera Barat}

Pengunjung Perpustakaan Daerah Propinsi Sumatera Barat terdiri dari masyarakat umum, pegawai negeri, mahasiswa, siswa SLTA dan SLTP. Gambaran minat baca pengunjung Perpustakaan Daerah Propinsi Sumatera Barat tersebut, terlihat pada Tabel 1.

Tabel 1. Minat Baca Masyarakat Umum sebagai Pengunjung Perpustakaan

\begin{tabular}{|c|c|c|c|c|c|c|c|c|c|c|c|c|}
\hline \multirow[t]{2}{*}{ No } & \multirow{2}{*}{ Indikator } & \multicolumn{2}{|c|}{$\mathrm{TP}$} & \multicolumn{2}{|c|}{$\mathrm{J}$} & \multicolumn{2}{|r|}{ K } & \multicolumn{2}{|r|}{$S$} & \multicolumn{2}{|c|}{ SS } & \multirow{2}{*}{$\mathrm{Jml}$} \\
\hline & & $f$ & $\%$ & $f$ & $\%$ & $f$ & $\%$ & $f$ & $\%$ & $f$ & $\%$ & \\
\hline 1. & $\begin{array}{l}\text { Perhatian terhadap } \\
\text { bahan bacaan }\end{array}$ & 2 & 2.59 & 16 & 20.79 & 7 & 9,01 & 26 & 33.76 & 26 & 33.76 & 77 \\
\hline 2. & Kesukaan membaca & 0 & 0 & 8 & 18.18 & 12 & 27.27 & 13 & 29.55 & 11 & 25 & 44 \\
\hline 3. & $\begin{array}{l}\text { Penilaian terhadap } \\
\text { bahan bacaan }\end{array}$ & 0 & 0 & 8 & 12.12 & 10 & 15.15 & 25 & 37.88 & 23 & 34.85 & 66 \\
\hline 4. & $\begin{array}{l}\text { Melakukan pilihan } \\
\text { dan penseleksian } \\
\text { bahan bacaan }\end{array}$ & 0 & 0 & 1 & 2.27 & 9 & 20.45 & 20 & 45.45 & 14 & 31.82 & 44 \\
\hline & Jumlah & 2 & 0.86 & 33 & 14.30 & 38 & 16,45 & 84 & 36.36 & 74 & 32.03 & 231 \\
\hline
\end{tabular}

Keterangan : $S S=$ Sering sekali, $S=$ Sering, $K=$ Kadang-kadang, $J=$ Jarang dan TP = Tidak Pernah

Berdasarkan Tabel 1, menunjukkan sebanyak 36,36 \% masyarakat umum sebagai pengunjung Perpustakaan Daerah Propinsi Sumatera Barat memiliki kecenderungan yang dinyatakan dalam bentuk perilaku sering memperhatikan, memilih dan melakukan kegiatan membaca dengan perasaan senang membaca bahan yang akan dibacanya. Selanjutnya 32,03 \% sangat sering, 16,45\% kadang-kadang, 14,30\% kadang-kadang dan 0,86\% tidak pernah memiliki kecenderungan yang dinyatakan dalam bentuk perilaku memperhatikan, memilih dan melakukan kegiatan membaca dengan 
perasaan senang membaca bahan yang akan dibacanya. Dengan demikian sebagian masyarakat umum sebagai pengunjung Badan Perpustakaan Daerah Propinsi Sumatera Barat (sering sekali + sering $=$ $68,39 \%)$ telah berminat untuk membaca bahan bacaan yang disediakan. Walaupun demikian minat baca masyarakat umum sebagai pengunjung Perpustakaan Daerah Propinsi Sumatera Barat belum optimal, karena sisanya sebanyak 31,61 \% (16,45 \% kadang-kadang, 14,30 \% jarang dan 0,86\% tidak pernah) masyarakat umum sebagai pengunjung Perpustakaan Daerah Propinsi Sumatera Barat berminat untuk membaca bahan bacaan yang telah disediakan.

Selanjutnya minat baca pegawai negeri sebagai pengunjung Perpustakaan Daerah Propinsi Sumatera Barat terlihat pada Tabel 2.

Tabel 2.Minat Baca Pegawai sebagai Pengunjung Perpustakaan

\begin{tabular}{|c|c|c|c|c|c|c|c|c|c|c|c|c|}
\hline \multirow[b]{2}{*}{ No } & \multirow[b]{2}{*}{ Indikator } & \multicolumn{2}{|c|}{ TP } & \multicolumn{2}{|c|}{ J } & \multicolumn{2}{|c|}{ K } & \multicolumn{2}{|c|}{ S } & \multicolumn{2}{|c|}{ SS } & \multirow[b]{2}{*}{ Jml } \\
\hline & & $f$ & $\%$ & $f$ & $\%$ & $f$ & $\%$ & $f$ & $\%$ & $f$ & $\%$ & \\
\hline 1. & $\begin{array}{l}\text { Perhatian } \\
\text { terhadap } \\
\text { bahan bacaan }\end{array}$ & 7 & 7 & 10 & 10 & 15 & 15 & 25 & 25 & 43 & 43 & 100 \\
\hline 2. & $\begin{array}{l}\text { Kesukaan } \\
\text { membaca }\end{array}$ & 6 & 9.99 & 5 & 8.33 & 10 & 16.66 & 5 & 41.66 & 14 & 23.33 & 40 \\
\hline 3. & $\begin{array}{l}\text { Penilaian } \\
\text { terhadap } \\
\text { bahan bacaan }\end{array}$ & 2 & 2.29 & 1 & 1.14 & 13 & 14.94 & 37 & 42.52 & 34 & 39.08 & 87 \\
\hline 4. & $\begin{array}{l}\text { Melakukan } \\
\text { pilihan dan } \\
\text { penseleksian } \\
\text { bahan bacaan }\end{array}$ & 0 & 0 & 1 & 1.74 & 14 & 24.13 & 21 & 36.20 & 22 & 37.93 & 58 \\
\hline & Jumlah & 15 & 4.91 & 17 & 5.61 & 52 & 17.04 & 108 & 35.40 & 113 & 37.04 & 285 \\
\hline
\end{tabular}

Keterangan $: S S=$ Sering sekali, $S=$ Sering, $K=$ Kadang-kadang, $J=$ Jarang dan TP = Tidak Pernah

Berdasarkan Tabel 2, menunjukkan sebanyak 37,04 \% pegawai negeri sebagai pengunjung Perpustakaan Daerah Propinsi Sumatera Barat sangat sering memiliki kecenderungan yang dinyatakan dalam bentuk perilaku memperhatikan, memilih dan melakukan kegiatan membaca dengan perasaan senang. Selanjutnya $35,40 \%$ sering, 17,04\% kadang-kadang, 5,61\% jarang, 4,91\% tidak pernah pegawai negeri sebagai pengunjung perpustakaan memiliki kecenderungan yang dinyatakan dalam bentuk perilaku memperhatikan, memilih dan melakukan kegiatan membaca dengan perasaan senang. Dengan demikian sebagian (sering sekali + sering $=72,44 \%$ ) pegawai negeri sebagai pengunjung Perpustakaan Daerah Propinsi Sumatera Barat telah berminat untuk membaca bahan bacaan yang disediakan. Walaupun demikian minat baca pegawai negeri tersebut sebagai pengunjung Perpustakaan Daerah Propinsi Sumatera Barat belum optimal, karena sebanyak 27,56 \% (17,04 \% kadang-kadang, 5,61 \% jarang dan 4,91\% tidak 
pernah) pegawai sebagai pengunjung Perpustakaan Daerah Propinsi Sumatera Barat berminat membaca bahan bacaan yang disediakan secara optimal.

Di sisi lain, minat baca mahasiswa sebagai pengunjung Perpustakaan Daerah Propinsi Sumatera Barat terlihat pada Tabel 3.

Tabel 3.Minat Baca Mahasiswa sebagai Pengunjung Perpustakaan

\begin{tabular}{|c|c|c|c|c|c|c|c|c|c|c|c|c|}
\hline & \multirow[t]{2}{*}{ Indikator } & \multicolumn{2}{|c|}{ TP } & \multicolumn{2}{|c|}{ J } & \multicolumn{2}{|c|}{ K } & \multicolumn{2}{|c|}{$S$} & \multicolumn{2}{|c|}{ SS } & \multirow[t]{2}{*}{$\mathrm{Jml}$} \\
\hline & & $f$ & $\%$ & $f$ & $\%$ & $f$ & $\%$ & $f$ & $\%$ & $f$ & $\%$ & \\
\hline 1. & $\begin{array}{l}\text { Perhatian } \\
\text { terhadap bahan } \\
\text { bacaan }\end{array}$ & 8 & 4.10 & 18 & 9.23 & 57 & 29.23 & 47 & 24.10 & 65 & 33.33 & 195 \\
\hline 2. & $\begin{array}{l}\text { Kesukaan } \\
\text { membaca }\end{array}$ & 1 & 0.89 & 5 & 4.46 & 37 & 33.03 & 36 & 32.14 & 33 & 29.46 & 112 \\
\hline 3. & $\begin{array}{l}\text { Penilaian } \\
\text { terhadap bahan } \\
\text { bacaan }\end{array}$ & 1 & 0.61 & 7 & 4.16 & 31 & 18.45 & 75 & 44.64 & 54 & 32.14 & 168 \\
\hline 4. & $\begin{array}{l}\text { Melakukan } \\
\text { pilihan }\end{array}$ & - & 0 & 3 & 2.67 & 28 & 24.99 & 47 & 41.96 & 34 & 30.35 & 112 \\
\hline & Jumlah & 10 & 1.72 & 33 & 5.62 & 153 & 26.06 & 205 & 34.92 & 186 & 31.68 & 587 \\
\hline
\end{tabular}

Keterangan $: S S=$ Sering sekali, $S=$ Sering, $K=$ Kadang-kadang, $J=$ Jarang dan TP = Tidak Pernah

Berdasarkan Tabel 3, menunjukkan sebanyak 34,92 \% mahasiswa sebagai pengunjung Perpustakaan Daerah Propinsi Sumatera Barat sering memiliki kecenderungan yang dinyatakan dalam bentuk perilaku memperhatikan, memilih dan melakukan kegiatan membaca dengan perasaan senang. Selanjutnya 31,68 \% sangat sering, 26,06 \% kadang-kadang, 5,62\% jarang, dan 1,72\% tidak pernah mahasiswa sebagai pengunjung Perpustakaan Daerah memiliki kecenderungan yang dinyatakan dalam bentuk perilaku memperhatikan, memilih dan melakukan kegiatan membaca dengan perasaan senang. Dengan demikian sebagian (sering sekali + sering $=66.6 \%$ ) mahasiswa sebagai pengunjung perpustakaan telah berminat untuk membaca bahan bacaan yang disediakan perpustakaan. Walaupun demikian minat baca mahasiswa sebagai pengunjung Perpustakaan Daerah Propinsi Sumatera Barat belum optimal, karena sebanyak 33,4 \% (26,06 \% kadang-kadang, 5,62 \% jarang dan 1,72\% tidak pernah) mahasiswa sebagai pengunjung Perpustakaan Daerah Propinsi Sumatera Barat meminati bahan bacaan yang disediakan perpustakaan secara optimal.

Selanjutya minat baca siswa SLTA sebagai pengunjung Perpustakaan Daerah Propinsi Sumatera Barat terlihat pada Tabel 4. 
Tabel 4

Minat Baca Siswa SLTA sebagai Pengunjung Perpustakaan

\begin{tabular}{|c|c|c|c|c|c|c|c|c|c|c|c|c|}
\hline \multirow[t]{2}{*}{ No } & \multirow[t]{2}{*}{ Indikator } & \multicolumn{2}{|c|}{ TP } & \multicolumn{2}{|c|}{$\mathrm{J}$} & \multicolumn{2}{|c|}{ K } & \multicolumn{2}{|c|}{ S } & \multicolumn{2}{|c|}{ sS } & \multirow[t]{2}{*}{$\mathrm{Jml}$} \\
\hline & & $f$ & $\%$ & $f$ & $\%$ & $f$ & $\%$ & $f$ & $\%$ & $f$ & $\%$ & \\
\hline 1. & $\begin{array}{l}\text { Perhatian } \\
\text { terhadap } \\
\text { bahan bacaan }\end{array}$ & 8 & 5.45 & 15 & 10.20 & 48 & 32.65 & 44 & 29.93 & 32 & 21.76 & 147 \\
\hline 2 & $\begin{array}{l}\text { Kesukaan } \\
\text { membaca }\end{array}$ & 4 & 4.77 & 8 & 9.52 & 24 & 28.57 & 28 & 33.33 & 20 & 23.80 & 84 \\
\hline 3. & $\begin{array}{l}\text { Penilaian } \\
\text { terhadap } \\
\text { bahan bacaan }\end{array}$ & 0 & 0 & 6 & 4.81 & 20 & 16 & 58 & 46.40 & 41 & 32.80 & 125 \\
\hline 4. & $\begin{array}{l}\text { Melakukan } \\
\text { pilihan }\end{array}$ & 0 & 0 & 6 & 7.14 & 23 & 27.38 & 39 & 46.42 & 16 & 19.04 & 84 \\
\hline & Jumlah & 12 & 2.74 & 35 & 7.96 & 115 & 26.13 & 169 & 38.40 & 109 & 24.77 & 440 \\
\hline
\end{tabular}

Keterangan $: S S=$ Sering sekali, $S=$ Sering, $K=$ Kadang-kadang, $J=$ Jarang dan TP = Tidak Pernah

Berdasarkan Tabel 4, menunjukkan sebanyak 38,40 \% siswa Sekolah Lanjutan Tingkat Atas (SLTA) sebagai pengunjung Perpustakaan Daerah sering memiliki kecenderungan memperhatikan, memilih dan melakukan kegiatan membaca dengan perasaan senang. Selanjutnya 26,13\% kadangkadang, $24,77 \%$ sering sekali, 7,96 jarang dan 2,74 tidak pernah siswa SLTA sebagai pengunjung perpustakaan memiliki kecenderungan yang dinyatakan dalam bentuk perilaku memperhatikan, memilih dan melakukan kegiatan membaca dengan perasaan senang membaca bahan yang akan dibacanya. Dengan demikian sebagian (sering sekali + sering $=63.17 \%$ ) siswa SLTA sebagai pengunjung Perpustakaan Daerah telah berminat membaca bahan bacaan yang disediakan perpustakaan. Walaupun demikian minat baca siswa SLTA sebagai pengunjung Perpustakaan Daerah Propinsi Sumatera Barat belum optimal, karena sebanyak 36,83 \% (26,13\% kadang-kadang , 7,96 \% jarang dan 2,74\% tidak pernah) siswa SLTA sebagai pengunjung Perpustakaan Daeah meminati bahan bacaan yang disediakan perpustakaan secara optimal.

Di samping itu, minat baca siswa Sekolah Lanjutan Pertama (SLTP) sebagai pengunjung Perpustakaan Daerah Propinsi Sumatera terlihat pada Tabel 5. 
Tabel 5

Minat Baca Siswa SLTP sebagai Pengunjung Perpustakaan

\begin{tabular}{|c|c|c|c|c|c|c|c|c|c|c|c|c|}
\hline \multirow{2}{*}{ No } & \multirow{2}{*}{ Indikator } & \multicolumn{2}{|c|}{ TP } & \multicolumn{2}{|r|}{$\mathbf{J}$} & \multicolumn{2}{|c|}{$\mathrm{K}$} & \multicolumn{2}{|c|}{$\mathbf{S}$} & \multicolumn{2}{|c|}{ SS } & \multirow[t]{2}{*}{$\mathrm{Jml}$} \\
\hline & & $f$ & $\%$ & $f$ & $\%$ & $f$ & $\%$ & $f$ & $\%$ & $f$ & $\%$ & \\
\hline 1. & Perhatian terhadap bahan bacaan & 4 & 3.80 & 14 & 13.33 & 29 & 27.61 & 26 & 27.46 & 32 & 30.47 & 105 \\
\hline 2. & Kesukaan membaca & 4 & 6.66 & 9 & 14.99 & 14 & 23.33 & 18 & 29.99 & 15 & 24.99 & 60 \\
\hline 3. & Penilaian terhadap bahan bacaan & 2 & 2.22 & 4 & 4.44 & 23 & 25.55 & 29 & 32.22 & 32 & 35.55 & 90 \\
\hline 4. & Melakukan pilihan & 0 & 0 & 7 & 11.66 & 17 & 28.33 & 24 & 29.99 & 12 & 19.99 & 60 \\
\hline & Jumlah & 10 & 3.17 & 34 & 10.79 & 83 & 26.34 & 97 & 30.79 & 91 & 28.88 & 315 \\
\hline
\end{tabular}

Keterangan $: S S=$ Sering sekali, $S=$ Sering, $K=$ Kadang-kadang, $J=$ Jarang dan TP = Tidak Pernah

Berdasarkan tabel 5, menunjukkan sebanyak 30,79 \% siswa Sekolah Lanjutan Tingkat Pertama (SLTP) sebagai pengunjung Perpustakaan Daerah sering memiliki kecenderungan memperhatikan, memilih dan melakukan kegiatan membaca dengan perasaan senang. Selanjutnya $28,88 \%$ sering sekali, $26,34 \%$ kadang-kadang, 10,79 \% jarang, dan 3,17 \% tidak pernah siswa SLTP sebagai pengunjung Perpustakaan Daerah Propinsi Sumatera Barat memiliki kecenderungan yang dinyatakan dalam bentuk perilaku memperhatikan, memilih dan melakukan kegiatan membaca dengan perasaan senang. Dengan demikian sebagian (sering sekali + sering $=59,67 \%$ ) siswa SLTP sebagai pengunjung Perpustakaan Daerah Propinsi Sumatera Barat telah berminat membaca bahan bacaan yang disediakan perpustakaan. Walaupun demikian minat baca siswa SLTP sebagai pengunjung Perpustakaan Daerah Propinsi Sumatera Barat belum optimal, karena sebanyak 40,33 \% (26,34\% kadang-kadang, 10,79\% jarang dan 3,17 \% tidak pernah) siswa SLTP sebagai pengunjung perpustakaan berminat untuk membaca bahan bacaan yang disediakan perpustakaan secara optimal.

Secara umum minat baca pengunjung Perpustakaan Daerah Propinsi Sumatera Barat terlihat pada Tabel 6. 
Tabel 6. Minat Baca Pengunjung Perpustakaan Daerah Sumatera Barat

\begin{tabular}{|c|c|c|c|c|c|c|c|c|c|c|c|c|}
\hline \multirow[t]{2}{*}{ No. } & \multirow[t]{2}{*}{ Indikator } & \multicolumn{2}{|c|}{ TP } & \multicolumn{2}{|c|}{$\mathrm{J}$} & \multicolumn{2}{|c|}{$\mathrm{K}$} & \multicolumn{2}{|c|}{$S$} & \multicolumn{2}{|c|}{ SS } & \multirow[t]{2}{*}{$\mathrm{Jml}$} \\
\hline & & $f$ & $\%$ & $f$ & $\%$ & $f$ & $\%$ & $f$ & $\%$ & $f$ & $\%$ & \\
\hline 1. & $\begin{array}{l}\text { Perhatian } \\
\text { terhadap } \\
\text { bahan bacaan }\end{array}$ & 29 & 4,65 & 73 & 11,7 & 156 & 25 & 168 & 26.92 & 198 & 31.73 & 624 \\
\hline 2. & $\begin{array}{l}\text { Kesukaan } \\
\text { membaca }\end{array}$ & 15 & 4,41 & 35 & 10,3 & 97 & 28,53 & 100 & 29,4 & 93 & 27,35 & 340 \\
\hline 3. & $\begin{array}{l}\text { Penilaian } \\
\text { terhadap } \\
\text { bahan bacaan }\end{array}$ & 5 & 0.9 & 26 & 4,85 & 97 & 18,1 & 224 & 41,82 & 184 & 34.33 & 536 \\
\hline 4. & $\begin{array}{l}\text { Melakukan } \\
\text { pilihan dan } \\
\text { penseleksian } \\
\text { bahan bacaan }\end{array}$ & 0 & 0 & 18 & 5,03 & 91 & 25,42 & 151 & 42,18 & 98 & 27,37 & 358 \\
\hline & Jumlah & 49 & 2,85 & 152 & 8.83 & 441 & 25,6 & 507 & 29.44 & 573 & 33,28 & 1722 \\
\hline
\end{tabular}

Keterangan $: S S=$ Sering sekali, $S=$ Sering, $K=$ Kadang-kadang, $J=$ Jarang dan TP = Tidak Pernah

Berdasarkan Tabel 6, menunjukkan sebanyak 33,28 \% pengunjung Perpustakaan Daerah Propinsi Sumatera Barat sangat sering memiliki kecenderungan memperhatikan, memilih dan melakukan kegiatan membaca dengan perasaan senang. Selanjutnya 29,44\% sering, 25,6 \% kadang-kadang, 8,83 \% jarang, dan 2,85 \% tidak pernah pengunjung Perpustakaan Daerah Propinsi Sumatera Barat memiliki kecenderungan yang dinyatakan dalam bentuk perilaku memperhatikan, memilih dan melakukan kegiatan membaca dengan perasaan senang. Dengan demikian sebagian (sering sekali + sering $=62,72 \%$ ) pengunjung Perpustakaan Daerah Propinsi Sumatera Barat telah berminat membaca bahan bacaan yang disediakan perpustakaan. Walaupun demikian minat masyarakat sebagai pengunjung Perpustakaan Daerah Propinsi Sumatera Barat belum optimal, karena sebanyak 37,28 \% (25,6 \% kadang-kadang, 8,83 \% jarang dan 2,85\% tidak pernah) pengunjung perpustakaan sebagai responden penelitian berminat untuk membaca bahan bacaan yang disediakan perpustakaan sercara optimal.

\section{b. Pemanfaatan Perpustakaan oleh Pengunjung Badan Perpustakaan Daerah.}

Pemanfaatan koleksi Perpustakaan Daerah Propinsi Sumatera Barat dapat dilihat dari jumlah kunjungan dan tema-tema bahan bacaan yang telah dimanfaatkan masyarakat sebagai pengunjung perpustakaan. Berdasarkan jumlah kunjungan per minggu, terungkap pada Tabel 7. 
Tabel. 7.Jumlah Kunjungan Ke Perpustakaan Per Minggu

\begin{tabular}{|c|l|c|c|}
\hline No & \multicolumn{1}{|c|}{ Jumlah Kunjungan } & f & \% \\
\hline 1 & 1 x semingggu & 37 & 41.11 \\
2 & $2 \times$ seminggu & 24 & 26.67 \\
3 & 3 x seminggu & 13 & 14.44 \\
4 & 4 x seminggu & 9 & 10.00 \\
5 & Jarang & 7 & 7.78 \\
\hline \multicolumn{2}{r|}{ Jumlah } & 90 & 100 \\
\hline
\end{tabular}

Berdasarkan Tabel 7, ditemukan sebanyak 41,11 \% pengunjung Perpustakaan Daerah Propinsi Sumatera Barat mengunjungi perpustakaan sebanyak satu kali dalam seminggu. Selanjutnya 26,67\% mengunjungi perpustakaan sebanyak dua kali dalam seminggu, sebanyak 14,44 \% mengunjungi perpustakaan sebanyak tiga kali dalam seminggu, sebanyak $10 \%$ mengunjungi perpustakaan sebanyak empat kali seminggu dan sebanyak 7,78\% jarang mengunjungi perpustakaan. Dengan demikian sebagian besar $(92,22 \%)$ pengunjung perpustakaan mengunjungi perpustakaan minimal sebanyak satu kali dalam seminggu.

Bahan bacaan yang dimanfaatkan pengunjung Perpustakaan Daerah Sumatera Barat, terlihat pada Tabel 8 .

Tabel.8.Tema Bahan Bacaan yang Dimanfaatkan Pengunjung Perpustakaan

\begin{tabular}{|c|l|r|c|}
\hline No & \multicolumn{1}{|c|}{ Tema yang disukai } & f & $\%$ \\
\hline 1 & Umum, penerbitan, perpustakaan & 36 & 13.33 \\
2 & Filsafat dan psikologi & 35 & 12.96 \\
3 & Agama & 60 & 22.22 \\
4 & IImu sosial: politik, ekonomi, hukum, pendidikan & 40 & 14.81 \\
5 & Bahasa & 32 & 11.85 \\
6 & Ilmu murni: matematika, fisika, kimia, biologi & 25 & 9.26 \\
7 & IImu terapan: teknik, kedokteran, pertanian, peternakan & 28 & 10.38 \\
8 & Kesenian: arsitektur, musik, olah raga & 14 & 5.19
\end{tabular}

Berdasarkan tabel 8 , ditemukan sebanyak $22,22 \%$ pengunjung perpustakaan memanfaatkan bahan bacaan bertemakan agama, 14,81 \% memanfaatkan bahan bacaan bertemakan pendidikan, 13,33\% memanfaatkan bahan bacaan bertemakan umum, penerbitan, perpustakaan, 12,96 \% memanfaatkan bahan bacaan bertemakan filsafat dan psikologi, 11,85 \% memanfaatkan bahan bacaan bertemakan bahasa 10,37 
$\%$ memanfaatkan bahan bacaan bertemakan ilmu terapan: teknik, kedokteran, pertanian, peternakan, 9,26 $\%$ memanfaatkan bahan bacaan bertemakan Ilmu murni: matematika, fisika, kimia, biologi, 5,19 \% kesenian: arsitektur, musik, olah raga. Dengan demikian belum semua koleksi dimanfaatkan pengunjung secara optimal, karena sebagian pengunjung perpustakaan hanya memanfaatkan bahan bacaan bertemakan agama, pendidikan/ilmu social/politik/ekonomi, umum/penerbitan/perpustakaan, filsafat dan psikologi, bahasa dan ilmu murni. Tema bahan bacaan yang kurang dimanfaatkan pengunjung perpustakaan adalah kesenian : Arsitektu,musik dan olah raga.

\section{Pembahasan}

Pengunjung perpustakaan berminat untuk membaca bahan bacaan yang disediakan perpustakaan. Berdasarkan temuan penelitian diperoleh keterangan sebagian besar $(62,72 \%)$ pengunjung Perpustakaan Daerah Propinsi Sumatera Barat berminat membaca bahan bacaan yang disediakan perpustakaan. Walaupun demikian minat baca masyarakat sebagai pengunjung Perpustakaan Daerah Propinsi Sumatera Barat belum optimal, karena sebanyak 37,28 \% (25,6 \% kadang-kadang, 8,83 \% jarang dan 2,85\% tidak pernah) masyarakat sebagai

Kurang optimalnya minat baca masyarakat Pengunjung Perpustakaan Daerah Propinsi Sumatera Barat, memiliki tendensi tertentu sebagai hasil dari proses belajar. Hurlock (1999:116) menjelaskan seorang anak tidak dilahirkan lengkap dengan minatnya terhadap sesuatu objek. Bersamaan dengan hal itu, Hasan (1999 www.indolib.net/kolom/ko001.htm,) menjelaskan membaca merupakan kebiasaan dan bukan bawaan sejak lahir. Kebiasaan membaca berkembang dari tradisi lisan para orangtua melalui dongeng kepada anak-anaknya. Selanjutnya tradisi tersebut diambil alih ke dalam bentuk tulisan, kemudian dirangkum ke dalam bentuk buku. Keunggulan tradisi lisan memang mudah untuk disampaikan kepada anak, namun apa yang disampaikan itu tidak meninggalkan bekas. Kelebihan menulis adalah jejak yang ditinggalkan dapat dibaca berulang-ulang. Anak perlu diberikan fantasi dan fakta. Fantasi dapat dikembangkan menjadi fiksi, perkembangan selanjutnya dapat berubah menjadi fakta. Misalnya cerita Flash Gordon yang bercerita tentang penerbangan ke bulan, dianggap sebagai fantasi. Tapi sekarang, cerita itu sudah menjadi fakta.

Sehubungan dengan hal itu, Kholid A.Harras (2001 : www.isola-pos.upi.edu/txt/op-kholid.html) menjelaskan kurang mendukungnya minat baca masyarakat disebabkan oleh tradisi kelisanan (orality). Berabad-abad lamanya komunikasi masyarakat Indonesia sebagian besar berlangsung dalam tataran lisan ketimbang tradisi baca-tulis. Tradisi baca tulis baru dikenal secara terbatas oleh bangsa Indonesia sekitar pertengahan Abad VIII, sebagai akibat persentuhannya dengan agama serta kebudayaan Hindu, Budha, kemudian Islam. Sekitar pertengahan Abad XIX aktivitas baca-tulis tersebut mulai dikenal terbatas elit tertentu, sebagai akibat didirikannya lembaga persekolahan oleh pemerintah kolonial Belanda. Setelah kemerdekaan, pemerintah mendirikan persekolahan dan kegiatan membaca dan menulis mulai menyentuh secara lebih luas pada masyarakat umum. Selanjutnya kehadiran pendidikan formal tidak jarang menjadi penguat suburnya tradisi lisan dalam masyarakat. Proses belajar-mengajar yang berlangsung sebagian 
besar dalam lisan (guru menggunakan metode ceramah) ketimbang dalam tataran keberaksaraan. Guruguru jarang sekali memberi siswa tugas untuk membaca secara mandiri dari berbagai bahan bacaan yang ada di perpustakaan. Kondisi ini selanjutnya mempengaruhi kebiasaan siswa membeli dan memiliki buku sebagai kebutuhan.

Ekspresi minat dapat diketahui melalui suatu pernyataan dan aktifitas yang menunjukkan seseorang lebih menyukai sesuatu dari pada yang lain. Hurlock (1999:116-118) menjelaskan minat individu terhadap suatu objek mengandung aspek kognitif dan afektif. Aspek kognitif berkaitan dengan konsep bidang yang diminati, diperoleh dari pengalaman di rumah, sekolah dan masyarakat. Sedangkan aspek afektif minat dinyatakan dalam sikap terhadap kegiatan yang ditimbulkan minat dari pengalaman pribadi serta sikap orang-orang sekitar (seperti : orang tua, guru serta teman sebaya).

Selanjutnya Hurlock (1999:118) menjelaskan meskipun kedua aspek tersebut sama pentingnya, namun aspek afektif mempunyai peran yang lebih penting dari aspek kognitif. Hal ini disebabkan: (1) aspek afektif lebih besar perannya dalam memotivasi tindakan dari pada aspek kognitif, (2) aspek afektif yang sudah terbentuk cenderung lebih tahan terhadap perubahan dibandingkan aspek kognitif.

Di sisi lain, berdasarkan hasil penelitian juga ditemukan sebagian besar (92,22 \%) pengunjung perpustakaan sebagai responden penelitian mengunjunggi perpustakaan minimal sebanyak satu kali dalam seminggu. Walaupun demikian belum semua koleksi dimanfaatkan pengunjung secara optimal, karena sebagian pengunjung perpustakaan hanya memanfaatkan bahan bacaan bertemakan agama, pendidikan/ilmu social/politik/ekonomi, umum/penerbitan/perpustakaan, filsafat dan psikologi, bahasa dan ilmu murni.

Sehubungan dengan hal itu, kurang optimalnya pemanfaatan tema-tema buku yang telah disediakan bersumber dari kebutuhan masyarakat pengunjung Perpustakaan Daerah Propinsi Sumatera Barat. Wahyu Edie Purnomo (Sulistyo-Basuki, 1994 : 15) menjelaskan perpustakaan umum seharusnya memperhatikan tiga hal, yaitu (1) gedung/bangunan perpustakaan, (2) koleksi bahan pustaka dan (3) pelayanan pengguna perpustakaan. Pemilihan lokasi gedung perpustakaan umum sebaiknya berada di tempat yang strategis dan mudah dijangkau oleh masyarakat. Desain eksterior dan interior gedung berorientasi pada kenyamanan pengguna perpustakaan. Disediakan pula ruang koleksi khusus untuk anak-anak dan aula untuk keperluan diskusi, seminar, atau pameran. Koleksi bahan pustaka yang lengkap dan baru akan menarik kehadiran pengunjung perpustakaan. Koleksi bahan pustaka dibedakan dalam tiga jenis, yaitu: (1) buku-buku referensi (misalnya: ensiklopedia, kamus, direktori, penerbitan pemerintah, bibliografi, buku tahunan, almanak, indeks, abstrak, dan lain-lain), (2) buku-buku umum/teks yang dapat dibawa pulang, dan (3) koleksi terbitan berkala (misalnya: majalah, buletin, surat kabar, dan lain-lain). Dalam era teknologi informasi sekarang ini, sebaiknya disediakan pula koleksi audio-visual (misalnya: audio kaset, video kaset, CD-ROM, VCD, dan DVD) serta pelayanan internet.

Jumlah koleksi serta sarana dan prasarana pendukung di Perpustakaan Daerah Propinsi Sumatera Barat masih terbatas. Primantoro Nugroho (Suara Pembaruan, 19 Okt 2000) menjelaskan minat baca sama sekali tidak berhubungan dengan harga buku atau mitos-mitos lain yang selama ini berkembang. Minat 
baca akan terbentuk dengan sendirinya jika buku-buku yang ada di pasaran memang dianggap sesuai. Selama ini, masyarakat tidak dibiarkan merumuskan sendiri kebutuhan minat bacanya seperti apa. Rumusan itu selalu diambil alih oleh pihak-pihak lain seperti pemerintah atau industri bacaan.

Selanjutnya kurang optimalnya masyarakat pengunjung perpustakaan memanfaatkan koleksi yang ada, sesuai dengan temuan Unesco (Kholid A.Harras,2001 www.isola-pos.upi.edu/txt/op-kholid.html) yang mengungkapkan, dari sekitar 220 juta penduduk Indonesia yang belum bisa membaca atau dikatagorikan illiterat sebanyak 34,5 persen. Artinya cuma 65,5 persen saja yang sudah mampu melek huruf. Dari jumlah tersebut sebagian besar termasuk katagori kelompok aliterat, yakni mereka bisa membaca tetapi memilih untuk tidak menjadikan aktivitas membaca sebagai bagian dari tradisi hidupnya. Sedangkan masyarakat yang berkatagori literat, yang telah menjadikan aktivitas membaca sebagai bagian dari kebudayaan hidupnya, menurut sebuah hasil penelitian, jumlahnya tidak sampai 10 persen dari populasi bangsa ini.

Kurang optimalnya minat baca serta pemanfaatan koleksi perpustakaan juga bersumber dari pemerintah Kelurahan/Nagari, sekolah dan pengelola perpustakaan belum melakukan upaya dalam peningkatan minat baca masyarakat pengguna Perpustakaan Daerah Propinsi Sumatera Barat.

\section{Simpulan}

Berdasarkan temuan penelitian dan pembahasan dapat disimpulkan: (a) masyarakat pengunjung Perpustakaan Daerah Propinsi Sumatera Barat belum memiliki minat baca yang optimal terhadap koleksi yang telah disediakan perpustakaan, (b) sebagian besar masyarakat pengunjung Perpustakaan Daerah Propinsi Sumatera Barat mengunjunggi perpustakaan menimal satu kali dalam satu minggu.Koleksi yang telah disediakan belum dimanfaatkan pengunjung Perpustakaan secara optimal, karena sebagian pengunjung baru memanfaatkan bahan bacaan bertemakan agama, pendidikan/ilmu social/politik/ekonomi, umum/penerbitan/perpustakaan, filsafat dan psikologi, bahasa dan ilmu murni.

\section{Saran}

Berdasarkan temuan penelitian, disaran sebagai : (a) perlu melaksanakan sosialisasi melalui liflet, brosur dan pengumuman serta imbauan/pengumuman di Kelurahan/Nagari, RW/RT/Jorong, poskamling dan kedai/lapau tentang pentingnya perpustakaan/membaca dalam pengembangan Sumber Daya Manusia, (b) perlu mengembangkan program pembudayaan membaca melalui kegiatan : Lomba karya tulis, baca puisi/pidato, cerita anak, mengambar/mewarnai, serta program ilmiah dalam bentuk diskusi kelompok dan seminar untuk menyelesaikan berbagai permasalahan praktis dalam kehidupan masyarakat, (c) menjalin koordinasi dengan Dinas Pendidikan dalam peningkatan pembinaan perpustakaan sekolah, untuk kegiatan sosialisasi perpustakaan, penyusunan dan pelaksanaan program, penyediaan sarana-prasarana pendukung serta membangun jaringan dalam upaya meningkatkan minat baca siswa, (d) penyediaan kelengkapan koleksi serta ketersediaan sarana pendukung perpustakaan, seperti: VCD/DVD, Film, computer pada bagian pelayanan, rental computer, koperasi yang menyediaan alat tulis/rekaman, kavetaria, ruang baca, ruang bermain serta peralatan mobiler lainnya. (e) menjalin kerjasama dengan Dinas Pendidikan melakukan 
program pembinaan perpustakaan sekolah, menyangkut dengan : majamen perpustakaan, inventarisasi, keanggotaan, pembinaan SDM pengelola perpustakaan sekolah.

\section{DAFTAR KEPUSTAKAAN}

Adiningsih, Neni Utami 2002. 28 Mei Sistem Indoktrinasi Menekan Minat Baca Masyarakat Indonesia. Jakarta: Suara Merdeka, Selasa 28 Mei 2002.hlm 7.

Basuki,Sulistya.1994. Pengantar Ilmu Perpustakaan. Jakarta : Gramedia.

Basuki,Sulistya.1994.Potensi Perpustakaan dalam Menghadapi Krisis Sosial Budaya. Jakarta : Gramedia

Harras, Kholid A (2001): Menyambut International Literacy Day, Membaca Dan Tradisi Pendidikan Kita, www.isola-pos.upi.edu/txt/op-kholid.html, diakses 20 Februari 2004.

Hasan,Fuad, (1999) : TV Saingan Budaya Membaca (Republika, 29 Sep 1999) www.indolib.net/kolom/ko001.htm, diakses tanggal 20 Maret 2004

Hurlock, Elizabeth B (1978): Child Development. New York : McGraw Hill Book Company.

Nugroho (2000) : Bacaan yang Tersedia Kurang Penuhi Kebutuhan Masyarakat diterbitkan dalam Suara Pembaruan, 19 Okt 2000 